\title{
Feeding of Barbus cyclolepis Heckel, 1837 (Teleostei: Cyprinidae) and its relationship with benthic macroinvertebrate fauna in the Istranca Stream (İstanbul, Turkey)
}

\section{Barbus cyclolepis Heckel, 1837 (Teleostei: Cyprinidae)'in beslenmesi ve Istranca Deresi (İstanbul, Türkiye)'ndeki makroomurgasız faunası ile ilişkisi}

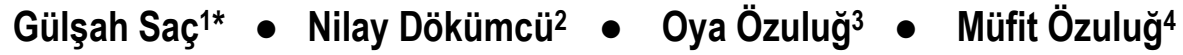 \\ 1 Istanbul University, Faculty of Aquatic Sciences, Department of Marine and Freshwater Resources Management, \\ 34134, Laleli, İstanbul, Turkey \\ 2 İstanbul University, Institute of Graduate Studies in Science and Engineering, 34134, Vezneciler, İstanbul, Turkey \\ 3 Istanbul University, Faculty of Science, Department of Biology, 34134, Vezneciler, İstanbul, Turkey \\ 4 İstanbul University, Faculty of Science, Department of Biology, 34134, Vezneciler, İstanbul, Turkey
}

(D) https://orcid.org/0000-0001-9988-1116

(D) https://orcid.org/0000-0003-4326-0753

https://orcid.org/0000-0002-9353-1366

(D) https://orcid.org/0000-0002-1437-3890

\section{How to cite this paper:}

Saç, G., Dökümcü, N., Özuluğ, O. \& Özuluğ, M. (2021). Feeding of Barbus cyclolepis Heckel, 1837 (Teleostei: Cyprinidae) and its relationship with benthic macroinvertebrate fauna in the Istranca Stream (İstanbul, Turkey). Ege Journal of Fisheries and Aquatic Sciences, 38(3), 345-353.

DOI: 10.12714/egejfas.38.3.11

\begin{abstract}
The aims of the study are to determine what the organisms Barbus cyclolepis consume as food in its feeding environments and to compare prey consumption with prey abundance in the environment. The study was conducted in the Istranca Stream located in Istanbul (Turkey) during the spring and summer of 2012. A total of $142 B$. cyclolepis specimens were captured and it is determined that 94 of them had full digestive tracts. Diet analyses of $B$. cyclolepis showed that its food spectrum consisted of 11 different food types, and the species was found to feed on insects, mainly Diptera (IRI\%= $92.26 \%$ ). The most abundant macroinvertebrate organisms in the environment were Diptera and Gastropoda. The electivity index of $B$. cyclolepis was positive for Diptera in the spring $(E=0.49)$, but the value was below the expected value of 0.6 for high selectivity. The electivity values for other macroinvertebrate groups, consumed in low proportions, were negative. In summer, the fish fed on Diptera, Plecoptera, and Trichoptera, but a high electivity index value was found only for Trichoptera $(E=0.87$ ). Results showed that $B$. cyclolepis mainly consumed Diptera as food and did not consume Gastropoda, although it is the second most abundant macroinvertebrate group in the environment. A relationship was determined between the proportion of food groups consumed in the digestive tracts of fish and the ratios of macroinvertebrates in the environment, and as a result, it was specified that the fish was selective on Diptera. Keywords: Barbus cyclolepis, diet, selectivity, benthic insects, stream, freshwater fish

Öz: Calısmanın amacı, Barbus cyclolepis'in beslenme ortamında hangi besinleri tükettiğini belirlemek ve av tüketimini cevredeki av bolluğu ile karşılaş̧ırmaktır. Çalışma 2012 ylı ilkbahar ve yaz aylarında İstanbul (Türkiye)'da bulunan Istranca Deresi'nde yürütülmüştür. Toplam 142 adet $B$. cyclolepis yakalanmıştır ve bunlardan 94 adedinin sindirim kanalının dolu olduğu tespit edilmiştir. Barbus cyclolepis'in diyet analizleri, türün besin spektrumunun 11 farklı besin türünden oluştuğunu ve başlıca Diptera $(\%|R|=\% 92,26)$ olmak üzere böceklerle beslendiği göstermiştir. Çalışma ortamında sayısal olarak en bol bulunan makroomurgasız organizmalar Diptera ve Gastropoda olarak belirlenmisțir. Barbus cyclolepis'in secicilik indeksi ilkbaharda Diptera için pozitif olarak belirlenmiş $(E=0,49)$ ancak değer, yüksek seçicilik açısından beklenen 0,6 değerinin altında bulunmuştur. Düşük oranlarda tüketilen diğer makroomurgasız grupları için ise seçicilik değerleri negatif olarak saptanmıştır. Yaz aylarında, Diptera, Plecoptera ve Trichoptera ile beslenen türde sadece Trichoptera $(E=0,87)$ için yüksek bir seçicilik indeksi değeri tespit edilmişstir. Sonuçlar, B. cyclolepis'in ağırlıklı olarak Diptera'yı besin olarak tükettiğini ve buna karşılık cevrede sayısal olarak en bol bulunan ikinci makroomurgasız grubu olmasına rağmen Gastropoda ile beslenmediğini saptamıştır. Balıkların sindirim sistemlerinde tüketilen besin gruplarının oranı ile çevredeki makroomurgasızların oranları arasında bir ilişki tespit edilmiş ve sonuçta türün Diptera üzerinde seçici olduğu belirlenmiştir.

Anahtar kelimeler: Barbus cyclolepis, besin, seçicilik, bentik böcekler, dere, tatlısu balığı
\end{abstract}

\section{INTRODUCTION}

Fish diet studies provide information about the food preferences of fish. The food items that the fish are fed are revealed by examining the contents of the stomach and information about their consumption rates are obtained. It is an important question whether the fish are fed randomly or by choosing the organisms found in the environment. The answer of this question can be found by comparing the number of each organism found in the stomach contents of fish and their proportions with the organisms living in the environment (Tupinambas et al., 2015)

Benthic macroinvertebrate species have an important role in the diet of many benthic fish species. Macroinvertebrates have an important place in the biodiversity of rivers and lakes, and they also act as nutrient recyclers, primary and secondary consumers, and food for wildlife (Keiper et al., 
2002). These organisms can also serve as ecological indicators to determine the productivity and water quality of aquatic environments (López-López and Sedeńo-Díaz, 2015).

Species of the genus Barbus are bottom-feeders and use their barbels to locate food (mostly bottom-dwelling and drifting benthic organisms) in the sediment. However, they are mostly small-sized rheophilic cyprinids, except a few species, (Antal et al., 2016) and usually found in riffle areas of streams because strong flow enhances the abundance of drift organisms such as macroinvertebrates in these gravel and rocky bottomed areas. Barbus cyclolepis Heckel, 1837, one of the members of this genus, spreads in a limited area in southeastern Europe (Kottelat and Freyhof, 2007). In the study conducted on the diet and feeding habits of this species, it was reported that the food of the population living in the Meriç River Basin is dominated by Chironomid larvae, followed by plant detritus and Gammarids (Rozdina et al., 2008). In the present study, the aim was to find answers to the following questions by temporally and spatially comparing the diet of $B$. cyclolepis in the Istranca Stream, where it inhabits together with various macroinvertebrate species:

1) what are the organisms that $B$. cyclolepis consume as food?

2) what is the selectivity of the fish in its feeding environment?

The presence/absence of available food sources or their abundance are the factors that can influence the feeding preference of a fish and in many of the feeding ecology studies. However, it is seen that the stomach contents of the fish are not compared with the possible food groups living in the environment. It is thought that the findings to be obtained as a result of the answers to these questions will contribute to other studies that will examine the interaction of fish species with other organisms in their habitats as well as their trophic levels.

\section{MATERIAL AND METHODS}

\section{Study area}

The study was conducted in the endorheic Istranca Stream, which is located in the northwest of Istanbul and flows into Lake Durusu (Figure 1, see Saç and Özuluğ, $2020 a, b)$. A total of 20 fish species belonging to seven families (Acheilognathidae, Cyprinidae, Cobitidae, Esocidae, Gobiidae, Gobionidae and Leuciscidae) inhabit the stream (Saç and Özuluğ, 2017). Fish and macroinvertebrate samplings were performed at six stations:

Taşlıgeçit Creek (St. $1-41.33098^{\circ} \mathrm{N}, 28.24897^{\circ} \mathrm{E}$ ) is a small and shallow stream with a mostly stony substrate. The stream bed mostly shows riffle characteristics,

Danamandıra Creek (St. $2-41.31415^{\circ} \mathrm{N}, 28.24893^{\circ} \mathrm{E}$ ) is a shallow stream and its substrate is mostly sandy and rarely stony, especially in riffle areas. It contains dense filamentous algae and submerged macrophytes in warm seasons as it is affected by domestic and agricultural pollution and animal waste,

Şeytan Creek (St. $3-41.41750^{\circ} \mathrm{N}, 28.13845^{\circ} \mathrm{E}$ ) is a small and shallow stream with stony (cobbles) substrate. It is wooded along the bank and the roots of the trees extend into the stream,

Binkılıç Creek (St. $\left.4-41.39901^{\circ} \mathrm{N}, 28.19366^{\circ} \mathrm{E}\right)$ shows different water depths depending on seasons and its substrate is mostly stony (gravel and cobbles). It is influenced by sewage discharge and domestic pollution,

Karamandere Creek (St. $5-41.37920^{\circ} \mathrm{N}, 28.29610^{\circ} \mathrm{E}$ ) is the deepest one with a mostly stony substrate (boulders and cobbles),

Karacaköy Creek (St. $6-41.39946^{\circ} \mathrm{N}, 28.38352^{\circ} \mathrm{E}$ ) shows different water depths depending on seasons and is influenced by sewage discharge and domestic pollution. The substrate is mostly sandy (Saç and Özuluğ, 2017).

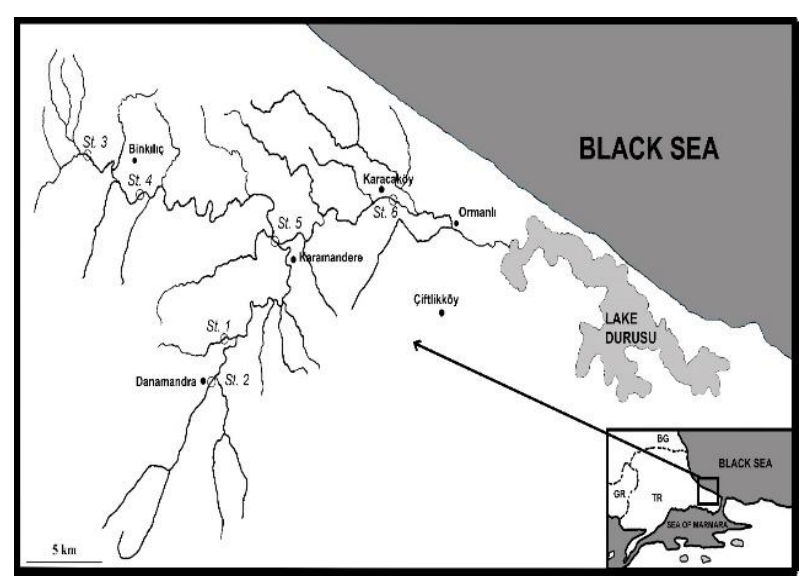

Figure 1. Study area (Istranca Stream, Lake Durusu Basin, Turkey) and sampling stations (St.1: Taşlıgeçit Creek; St.2: Danamandıra Creek; St.3: Şeytan Creek; St.4: Binkılıç Creek; St.5: Karamandere Creek; St.6: Karacaköy Creek)

\section{Fish and macroinvertebrate sampling}

Fish and aquatic macroinvertebrate samples were collected from the stations once a month (in spring 2012: March and April; in summer 2012: June and August). Since the aim of the study is to reveal the feeding relationship between fish and their possible preys, field surveys were conducted in the spring and summer months, when the food supply in the environment and the feeding activity of the fish were the highest. Fish specimens were captured by electrofishing (SAMUS 725G portable electro-shockers; frequency $50-55 \mathrm{~Hz}$; the grab net has a mesh size of $3 \mathrm{~mm}$ ) from the same points of the stations (approximately $50 \mathrm{~m}$ long sampling sections) and transferred to the laboratory in cold conditions (portable freezer, $-18^{\circ} \mathrm{C}$ ). The aquatic macroinvertebrate samples were collected by a special handnet with a $0.5 \mathrm{~mm}$ mesh-size against the direction of the water flow within a $1 \mathrm{~m}^{2}$ quadrat area. Organisms were collected 
into the net by moving this hand-net slowly over the fixed distance of the quadrat. Then, the collected samples were stored in plastic bottles and fixed with $4 \%$ formaldehyde solution.

\section{Laboratory studies}

Fish samples were measured for standard length (SL) to the nearest $0.1 \mathrm{~cm}$ and their total body weight (W) was weighed using a digital balance with a $0.01 \mathrm{~g}$ accuracy. To determine the diet composition, the digestive tracts were removed from the fish specimens and fixed in $4 \%$ formaldehyde solution. The prey items were identified to the lowest possible taxonomic level using a binocular microscope. Each taxonomic group was counted individually and then oven dried at $80^{\circ} \mathrm{C}$ and dried items weighed to the nearest $0.0001 \mathrm{~g}$.

The bottom sediment samples which contain macroinvertebrates were washed under high-pressure tap water using sieves (mesh size 1; 0.25; $0.16 \mathrm{~mm}$ ), and each organism was preserved in $70 \%$ ethyl alcohol. The macroinvertebrates both in the environment and in the digestive tract of fish samples were identified according to Askew (1988), Nilsson (1996, 1997), Zwick (2004), Oscoz et al. (2011) and Bouchard (2012).

\section{Data analyses}

The feeding habit of the fish was determined by indices of relative importance. The modified index of relative importance (Ml\%, see Hayse, 1990) for major prey items (such as Crustacea, Algae, Detritus, etc.) was estimated as:

$$
\mathrm{MI} \%=[(\mathrm{F} \% \times \mathrm{W} \%) / \Sigma(\mathrm{F} \% \times \mathrm{W} \%)] \times 100 .
$$

The index of relative importance (IRI\%) only for each countable insect groups was estimated as:

$$
\text { IRI\%=[((N\%+W\%) XF\%) / } \Sigma((\mathrm{N} \%+\mathrm{W} \%) \times \mathrm{F} \%)] \times 100,
$$

where $\mathrm{F} \%$ is the percentage of frequency of occurrence [(number of digestive tracts containing a food item/total number of digestive tracts with food) $\times 100], \mathrm{N} \%$ is the numerical percentage of digestive tracts with a certain food item against the total number of digestive tracts, and $\mathrm{W} \%$ is the gravimetric percentage of a certain food item against the weight of all consumed taxa (Hyslop, 1980).

To determine the niche breadth of $B$. cyclolepis, Levins' standardized niche breadth (Hurlbert, 1978) index was calculated: $B_{A}=(B-1) /(n-1)$, where $B$ is Levins' measure of niche breadth (Levins, 1968), $P_{j}$ is the proportion of individuals found using resource $j$, and $n$ is the number of possible resource states. Levins' standardized $B_{A}$ determines the measure of niche breadth on a scale from 0 to $1 . A B_{A}$ value close to 0 indicates a narrower diet (minimum niche breadth) and more specialization, and a $B_{A}$ value close to 1 indicates a broader diet (species consumes available food items in equal proportion) and more generalization (Krebs,
1998). Values of $B_{A}$ are considered high when higher than 0.6 , intermediate when between 0.4 and 0.6 , and low when below 0.4 (Novakowski et al., 2008).

The macroinvertebrates in the environment were identified and the specimens of each taxon were counted for the determination of $\mathrm{Ne} \%$ (relative abundance of each food item in the environment) with the following equation;

$\mathrm{N}_{\mathrm{e}} \%=$ specimen numbers of a taxon $\left(\mathrm{N}_{\mathrm{e}}\right) /$ total specimen number of all taxa (total $\left.\mathrm{N}_{\mathrm{e}}\right) \times 100$ (Kocataş, 2008).

The Ivlev's electivity index $(E)$ was calculated to evaluate the prey preferences of the fish. The index formula is as follows: $E=\left(r_{i}-P_{i}\right) /\left(r_{i}+P_{i}\right)$, where $E=$ electivity index, $\mathrm{r}_{\mathrm{i}}=$ percentage of food item $i$ in the diet $\left(\mathrm{N}_{\mathrm{f}} \%\right), \mathrm{P}_{\mathrm{i}}=$ percentage of food item $i$ in the environment $\left(\mathrm{N}_{\mathrm{e}} \%\right)$. The value of $E$ ranges from -1 to +1 and it indicates positive selectivity when it is above 0 and negative when less than 0 . The selectivity is accepted as high for values equal or higher than 0.6 (Pinto and Uieda, 2007).

\section{RESULTS}

\section{Fish diet and feeding ecology}

A total of 142 B. cyclolepis specimens were captured (spring: 58 specimens, $2.6-10.6 \mathrm{~cm} \mathrm{SL}, 0.42-21.28 \mathrm{~g} \mathrm{~W}$; summer: 84 specimens, $2.2-14.2 \mathrm{~cm} \mathrm{SL}, 0.21-57.01 \mathrm{~g} \mathrm{~W}$ ) and $66 \%$ of them $(72 \%$ in spring, $2.6-10.6 \mathrm{~cm} \mathrm{SL}, 0.42-21.28 \mathrm{~g} \mathrm{~W}$; $62 \%$ in summer, $3.1-11.6 \mathrm{~cm} \mathrm{SL}, 0.61-35.52 \mathrm{~g} \mathrm{~W}$ ) had full digestive tract. The individual distribution of the fish according to the stations and the digestive tract occupancy rates are as follows: in St.1, 9 specimens with 89\%; in St. 2, 44 specimens with $80 \%$; in St. 3, 24 specimens with $63 \%$; in St. 4, 12 specimens with $25 \%$; in St. 5, 20 specimens with $35 \%$; St. 6, 33 individuals with $79 \%$. The diet of $B$. cyclolepis consisted of five major food components: Insecta, Arachnida (Acaridae), Crustacea (Gammaridae), Algae and detritus. It was determined that the fish mainly fed on insects (MI\% was $96.15 \%$ in spring and $98.04 \%$ in summer, see Table 1). The insects consumed were represented by seven different groups (Diptera, Ephemeroptera, Plecoptera, Odonata, Trichoptera, Coleoptera, Hymenoptera) and Diptera was preferred as the main food with the highest values of relative importance among these groups (Table 2). MI\% and IRI\% values of food items were also estimated for each sampling station and shown in Table 3. In each habitat, fish has mainly consumed insects and among them, Diptera was the main food item in every station except St. 4.

Levins' standardized niche breadth $\left(B_{A}\right)$ for all specimens captured in the study period was estimated at 0.32 . In spring, $B_{A}$ value was 0.40 , and 0.31 in summer. The results showed that the food spectrum of $B$. cyclolepis was low in both seasons. Niche breadth values were also calculated separately according to the stations and were recorded as $0.70,0.41,0.49,0.79,0.60$ and 0.60 , respectively. 
Table 1. The major food composition in the diet B. cyclolepis in the Istranca Stream (n: number of fish, $F(\%)$ : The percentage of frequency of occurrence, W (\%): The percentage of dry gravimetric composition, $\mathrm{Ml}(\%)$ : modified index of relative importance for major prey items)

\begin{tabular}{|c|c|c|c|c|c|c|}
\hline \multirow[t]{2}{*}{ Food components } & \multicolumn{3}{|c|}{ Spring $(n=42)$} & \multicolumn{3}{|c|}{ Summer $(n=52)$} \\
\hline & $\mathrm{F} \%$ & $\mathrm{~W} \%$ & $\mathrm{Ml} \%$ & $\mathrm{~F} \%$ & $\mathrm{~W} \%$ & $\mathrm{Ml} \%$ \\
\hline Insecta & 66.67 & 85.10 & 96.15 & 82.69 & 83.41 & 98.04 \\
\hline Algae & 9.52 & 4.10 & 0.66 & 5.77 & 7.74 & 0.63 \\
\hline Crustacea (Gammaridae) & 4.76 & 0.88 & 0.07 & 5.77 & 1.46 & 0.12 \\
\hline Arachnida (Acaridae) & 4.76 & 0.34 & 0.03 & 5.77 & 0.12 & 0.01 \\
\hline Detritus & 19.05 & 9.58 & 3.09 & 11.54 & 7.26 & 1.19 \\
\hline
\end{tabular}

Table 2. The values of the index of the relative importance for Insecta groups in the diet of $B$. cyclolepis in the Istranca Stream (n: number of fish, $\mathrm{F}(\%)$ : The percentage of frequency of occurrence, $\mathrm{W}(\%)$ : The percentage of dry gravimetric composition, $\mathrm{N}(\%)$ : Numerical percentage, IRI (\%): index of relative importance for countable Insecta groups)

\begin{tabular}{|c|c|c|c|c|c|c|c|c|}
\hline \multirow{2}{*}{ Food items } & \multicolumn{4}{|c|}{ Spring $(n=42)$} & \multicolumn{4}{|c|}{ Summer $(n=52)$} \\
\hline & $\mathrm{F} \%$ & W\% & $\mathrm{N} \%$ & IRI\% & $\mathrm{F} \%$ & W\% & $\mathrm{N} \%$ & IRI\% \\
\hline Diptera & 52.38 & 26.01 & 96.27 & 93.25 & 75.00 & 48.14 & 95.74 & 90.58 \\
\hline Ephemeroptera & 7.14 & 0.35 & 0.25 & 0.06 & 21.15 & 14.66 & 1.71 & 2.91 \\
\hline Plecoptera & 2.38 & 0.08 & 0.17 & 0.01 & 7.69 & 0.92 & 0.20 & 0.07 \\
\hline Trichoptera & 30.95 & 5.88 & 3.23 & 4.14 & 40.38 & 16.61 & 2.21 & 6.38 \\
\hline Hymenoptera & 2.38 & 52.78 & 0.08 & 1.85 & 1.92 & 0.85 & 0.05 & 0.01 \\
\hline Odonata & - & - & - & - & 1.92 & 1.89 & 0.02 & 0.03 \\
\hline Coleoptera & - & - & - & - & 3.85 & 0.34 & 0.07 & 0.01 \\
\hline
\end{tabular}

Table 3. The values of the importance indices of food items in the diet of $B$. cyclolepis for each station in the Istranca Stream (n: number of fish, MI (\%): modified index of relative importance for major prey items; IRI (\%): index of relative importance for countable Insecta groups)

\begin{tabular}{|c|c|c|c|c|c|c|c|c|c|c|c|c|}
\hline \multirow[b]{2}{*}{ Food items } & \multicolumn{2}{|c|}{$\begin{array}{l}\text { Station-1 } \\
(n=8)\end{array}$} & \multicolumn{2}{|c|}{$\begin{array}{l}\text { Station-2 } \\
(n=35)\end{array}$} & \multicolumn{2}{|c|}{$\begin{array}{l}\text { Station-3 } \\
(n=3)\end{array}$} & \multicolumn{2}{|c|}{$\begin{array}{l}\text { Station-4 } \\
(n=15)\end{array}$} & \multicolumn{2}{|c|}{$\begin{array}{l}\text { Station-5 } \\
(n=7)\end{array}$} & \multicolumn{2}{|c|}{$\begin{array}{l}\text { Station-6 } \\
(n=26)\end{array}$} \\
\hline & $\mathrm{MI} \%$ & IRI\% & $\mathrm{MI} \%$ & IRI\% & $\mathrm{Ml} \%$ & IRI\% & $\mathrm{Ml} \%$ & IRI\% & $\mathrm{MI} \%$ & IRI\% & $\mathrm{Ml} \%$ & IRI\% \\
\hline Algae & - & & 0.20 & & - & & - & & 3.14 & & 5.73 & \\
\hline Gammaridae & 13.70 & & - & & 0.07 & & - & & - & & - & \\
\hline Acaridae & - & & 0.14 & & 0.02 & & - & & 0.14 & & - & \\
\hline Detritus & - & & 3.15 & & 5.23 & & - & & - & & 6.46 & \\
\hline Insecta & 86.30 & & 96.52 & & 94.68 & & 100.00 & & 96.73 & & 87.81 & \\
\hline Diptera & & 71.89 & & 90.96 & & 85.21 & & 37.57 & & 54.83 & & 99.56 \\
\hline Ephemeroptera & & 5.95 & & 0.87 & & 2.18 & & 61.36 & & - & & - \\
\hline Plecoptera & & 1.12 & & - & & 0.95 & & - & & - & & - \\
\hline Trichoptera & & 20.84 & & 5.67 & & 11.26 & & 1.07 & & 45.17 & & 0.44 \\
\hline Hymenoptera & & - & & 2.44 & & - & & - & & - & & - \\
\hline Odonata & & - & & 0.06 & & - & & - & & - & & - \\
\hline Coleoptera & & 0.20 & & - & & 0.10 & & - & & - & & - \\
\hline
\end{tabular}




\section{Macroinvertebrate composition on the environment}

A total of 1272 specimens of macroinvertebrates were sampled during the study period (601 specimens in spring; 671 specimens in summer). Specimens were grouped within the same level as food items in the digestive tract of sampled fish.

Detailed information about the taxa and the numbers of specimens is given in Table 4. In spring, the most abundant macroinvertebrates were dipteran larvae ( $\left.\mathrm{Ne}_{\mathrm{e}}: 198 ; \mathrm{Ne} \%: 32.94\right)$ followed by Gastropoda ( $\mathrm{N}_{\mathrm{e}}: 196 ; \mathrm{N}_{\mathrm{e}} \%: 32.61$ ). Similarly, in summer, dipterans were also prevailing ( $\mathrm{N}_{\mathrm{e}}: 446 ; \mathrm{N}_{\mathrm{e}} \%$ : 66.47). However, the number of gastropods did not increase as much as dipterans. The distribution of macroinvertebrates and their proportions in each sampling station are shown in Table 5. Macroinvertebrates diversity and the number of individuals were highest at St. 2, followed by St. 5 and St. 6 .

Table 4. Macroinvertebrate taxa and their seasonally specimen numbers $\left(\mathrm{N}_{\mathrm{e}}\right)$ and percentage $\left(\mathrm{N}_{\mathrm{e}} \%\right)$ in the environment (Istranca Stream)

\begin{tabular}{lllll}
\hline \multirow{2}{*}{ Taxa } & \multicolumn{3}{l}{ Spring } & \multicolumn{3}{l}{ Summer } & \\
\cline { 2 - 5 } & $\mathrm{N}_{\mathrm{e}}$ & $\mathrm{N}_{\mathrm{e}} \%$ & $\mathrm{~N}_{\mathrm{e}}$ & $\mathrm{N}_{\mathrm{e}} \%$ \\
\hline Diptera & 198 & 32.95 & 446 & 66.47 \\
Ephemeroptera & 36 & 5.99 & 20 & 2.98 \\
Plecoptera & 4 & 0.67 & 1 & 0.15 \\
Trichoptera & 23 & 3.83 & 1 & 0.15 \\
Odonata & 10 & 1.66 & 19 & 2.83 \\
Coleoptera & 1 & 0.17 & 6 & 0.89 \\
Gammaridae & 123 & 20.47 & 6 & 0.89 \\
Gastropoda & 196 & 32.61 & 151 & 22.50 \\
Bivalvia & 1 & 0.17 & 7 & 1.04 \\
Hemiptera & 9 & 1.50 & 14 & 2.09 \\
\hline Total N & 601 & & 671 & \\
\hline
\end{tabular}

Table 5. Macroinvertebrate taxa and their specimen numbers $\left(\mathrm{N}_{\mathrm{e}}\right)$ and percentage $\left(\mathrm{N}_{\mathrm{e}} \%\right)$ in each sampling station in the Istranca Stream

\begin{tabular}{|c|c|c|c|c|c|c|c|c|c|c|c|c|}
\hline \multirow{2}{*}{ Taxa } & \multicolumn{2}{|c|}{ Station-1 } & \multicolumn{2}{|c|}{ Station-2 } & \multicolumn{2}{|c|}{ Station-3 } & \multicolumn{2}{|c|}{ Station-4 } & \multicolumn{2}{|c|}{ Station-5 } & \multicolumn{2}{|c|}{ Station-6 } \\
\hline & $\mathrm{N}_{\mathrm{e}}$ & $\mathrm{N}_{\mathrm{e}} \%$ & $\mathrm{~N}_{\mathrm{e}}$ & $\mathrm{N}_{\mathrm{e}} \%$ & $\mathrm{~N}_{\mathrm{e}}$ & $\mathrm{N}_{\mathrm{e}} \%$ & $\mathrm{Ne}_{\mathrm{e}}$ & $\mathrm{N}_{\mathrm{e}} \%$ & $\mathrm{~N}_{\mathrm{e}}$ & $\mathrm{N}_{\mathrm{e}} \%$ & $\mathrm{~N}_{\mathrm{e}}$ & $\mathrm{N}_{\mathrm{e}} \%$ \\
\hline Diptera & - & - & 272 & 59.52 & 29 & 49.15 & 139 & 97.89 & 38 & 9.79 & 166 & 83.00 \\
\hline Ephemeroptera & 6 & 24.00 & 14 & 3.06 & 17 & 28.81 & 3 & 2.11 & 5 & 1.29 & 11 & 5.50 \\
\hline Plecoptera & 2 & 8.00 & - & - & 2 & 3.39 & - & - & 1 & 0.26 & - & - \\
\hline Trichoptera & 7 & 28.00 & 14 & 3.06 & 1 & 1.69 & - & - & 1 & 0.26 & 1 & 0.50 \\
\hline Odonata & 4 & 16.00 & 8 & 1.75 & 6 & 10.17 & - & - & 4 & 1.03 & 7 & 3.50 \\
\hline Coleoptera & - & - & - & - & - & - & - & - & - & - & 6 & 3.00 \\
\hline Gammaridae & - & - & 127 & 27.79 & 1 & 1.69 & - & - & - & - & 1 & 0.50 \\
\hline Gastropoda & - & - & 2 & 0.44 & 1 & 1.69 & - & - & 338 & 87.11 & 6 & 3.00 \\
\hline Bivalvia & - & - & 7 & 1.53 & - & - & - & - & - & - & 1 & 0.50 \\
\hline Hemiptera & 6 & 24.00 & 13 & 2.84 & 2 & 3.39 & - & - & 1 & 0.26 & 1 & 0.50 \\
\hline Total N & 25 & & 457 & & 59 & & 142 & & 388 & & 200 & \\
\hline
\end{tabular}

\section{Food selectivity}

According to the values of the electivity index, $B$. cyclolepis had a high selectivity $(+1)$ for Hymenoptera and Arachnida (Table 6). Diptera was the main food item of $B$. cyclolepis sampled in the area during spring (Table 6), but the electivity index was not high $(E<0.6)$. Other macroinvertebrate groups were consumed in low proportions by the fish and the electivity was calculated as negative. In summer, the fish consumed Diptera, Plecoptera and Trichoptera, but a high electivity index was estimated only for Trichoptera $(E>0.6)$. When analyzed according to the stations, there was selectivity in all stations except the St. 4 on Diptera, but the index value was significant in terms of high selectivity in only two stations (St. 1 and St. 5). In St. 3 and St. 5, B. cyclolepis showed high selectivity on Trichoptera, as well (Table 7). 
Table 6. Electivity index (E) values calculated for B. cyclolepis sampled in the Istranca Stream during spring and summer seasons ( $\mathrm{r}_{\mathrm{i}}=$ percentage of food item $i$ in the diet $(\mathrm{N} \%), \mathrm{P}_{\mathrm{i}}=$ percentage of food item $i$ in the environment $\left(\mathrm{Ne}_{\mathrm{e}} \%\right)$ ). Values in boldface indicate positive selectivity by the fish

\begin{tabular}{|c|c|c|c|c|c|c|}
\hline \multirow[t]{2}{*}{ Food items } & \multicolumn{3}{|c|}{ Spring } & \multicolumn{3}{|c|}{ Summer } \\
\hline & $r_{i}(\%)$ & $P_{i}(\%)$ & $E$ & $r_{i}(\%)$ & $P_{i}(\%)$ & $E$ \\
\hline Diptera & 95.95 & 32.95 & 0.49 & 95.54 & 66.47 & 0.18 \\
\hline Ephemeroptera & 0.25 & 5.99 & -0.92 & 1.71 & 2.98 & -0.27 \\
\hline Plecoptera & 0.17 & 0.67 & -0.60 & 0.25 & 0.15 & 0.25 \\
\hline Trichoptera & 3.22 & 3.83 & -0.09 & 2.18 & 0.15 & 0.87 \\
\hline Odonata & - & 1.66 & -1 & 0.02 & 2.83 & -0.98 \\
\hline Coleoptera & - & 0.17 & -1 & 0.07 & 0.89 & -0.85 \\
\hline Hemiptera & - & 1.50 & -1 & - & 2.09 & -1 \\
\hline Gammaridae & 0.17 & 20.47 & -0.98 & 0.07 & 0.89 & -0.85 \\
\hline Hymenoptera & 0.08 & - & 1 & 0.05 & - & 1 \\
\hline Bivalvia & - & 0.17 & -1 & - & 1.04 & -1 \\
\hline Gastropoda & - & 32.61 & -1 & - & 22.50 & -1 \\
\hline Arachnida & 0.17 & - & 1 & 0.10 & - & 1 \\
\hline
\end{tabular}

Table 7. Electivity index $(E)$ values calculated for B. cyclolepis captured in each station in the Istranca Stream. Values in boldface indicate positive selectivity by the fish

\begin{tabular}{|c|c|c|c|c|c|c|}
\hline Food items & Station-1 & Station-2 & Station-3 & Station-4 & Station-5 & Station-6 \\
\hline Diptera & 1 & 0.24 & 0.28 & -0.31 & 0.80 & 0.09 \\
\hline Ephemeroptera & -0.57 & -0.37 & -0.83 & 0.91 & -1 & -1 \\
\hline Plecoptera & -0.60 & - & -0.27 & - & -1 & - \\
\hline Trichoptera & -0.17 & -0.36 & 0.56 & 1 & 0.96 & 0.35 \\
\hline Odonata & -1 & -0.96 & -1 & - & -1 & -1 \\
\hline Coleoptera & 1 & - & 1 & - & - & -1 \\
\hline Hemiptera & -1 & -1 & -1 & - & -1 & -1 \\
\hline Gammaridae & 1 & -1 & -0.72 & - & - & -1 \\
\hline Hymenoptera & - & 1 & 1 & - & - & - \\
\hline Bivalvia & - & -1 & - & - & - & -1 \\
\hline Gastropoda & - & -1 & -1 & - & - & -1 \\
\hline Arachnida & - & 1 & 1 & - & 1 & - \\
\hline
\end{tabular}

\section{DISCUSSION}

The present study proved that $B$. cyclolepis is a typical benthophagous and insectivorous fish that was also feeding on a small number of plants and other animals (Table 1). In both seasons, Insecta ranked first in this species' food preference. Diptera and Trichoptera played the most important role in the diet of $B$. cyclolepis and the domination of dipteran larvae in the diet of other species of barbels was also reported from many studies (Collares-Pereira et al., 1996; Piria et al., 2005; Rozdina et al., 2008; Sapounidis et al., 2015). Dipterans are one of the most abundant macroinvertebrate groups in freshwater environments and these prolific organisms produce large populations (Keiper et al., 2002; Gülbunar et al., 2018). Dipteran larvae sometimes attach themselves to structures on the bottom but are often free-swimming and suspended off the bottom. High nutritional value, stabile availability, abundance and visibility make dipteran larvae easy prey for many fish species. Considering that Diptera was the most abundant insect group in the Istranca Stream, it is not surprising that they were the most important food for the benthic $B$. cyclolepis. Although Diptera is consumed as the main food by fish, the electivity index did not show a significant value on it as it is still the most abundant group in the environment. The total amount of algae, Crustacea and Arachnida, which are other food groups in the stomach, is very low compared to Insecta.

When the seasonal diet of the species was compared, it was observed that the diversity and abundance of food consumed increased during the summer months (Table 1, Table 2). While Ephemeroptera and Trichoptera were consumed in both seasons, their importance values increased in summer. Besides, it has been observed that Odanata and Coleoptera, which are not found in the stomach in spring, are consumed in summer feeding. However, since these two food groups are represented with low values in the environment, it is an expected result that the values found in the stomach in summer are also low.

No spatial difference was determined in the diet of the species and it preferred Insecta and especially Diptera as the main food at each station. Station 1 and St. 3 are streams 
located in the headwater of the Istranca Stream and display similar habitat characteristics and their food supplies have reflected in the food preference of fish. EPT (Ephemeroptera, Plecoptera, and Trichoptera) species mostly prefer the clean headwaters of the river systems (Hamid and Rawi, 2017), and their presence in the diet of fish may be related to their preference for those stations. However, the water quality in St. 4 was influenced by sewage discharge and domestic pollution (Saç and Özuluğ, 2017), and it is thought that this situation has influenced both the presence of fish as well as macroinvertebrates and the feeding of the fish. The environment was represented by only two macroinvertebrate species (Diptera and Ephemeroptera) and in addition to these, only one individual of Trichoptera was found in the digestive tract of the fish (Table 3 and Table 5). Despite the density of plants, the fish mainly fed on insects instead of them at St. 2. However, it was determined that the food preference of the fish was especially focused on Diptera and Trichoptera at St. 5 and St. 6 where insects decreased numerically, and the value of plants increased relatively in the diet of the fish due to the poor food supply of the environment.

According to Rozdina et al. (2008), the diet of $B$. cyclolepis inhabited in the Meriç River Basin consisted of 14 food components and was dominated by Chironomid larvae (Diptera), followed by plant and Gammaridae. The results of our study largely overlap with the results of this previous study in terms of both the food groups consumed by the fish and the dominance of Diptera in its diet. The other similarity of the results of these two studies is the seasonal activity in feeding and that both populations had a peak in summer.

When the macroinvertebrates in the environment are examined, the most abundant group is Insecta, followed by Gastropoda and Gammaridae. As in the stomach content, the most abundant group in Insecta is Diptera. Diptera has numerically increased 2.25 times in summer (Table 3 ). This result may be related to the active reproduction activity of different dipteran groups at different times of the year (Thorp and Covich, 2001). Nevertheless, the consumption proportions of the Diptera by the fish are very close in spring (93.25\%) and summer (90.58\%) (Table 2).

During the two sampling seasons, Gastropoda was the second most abundant macroinvertebrate group in the environment. However, no gastropods were found in the digestive tract of $B$. cyclolepis. It is thought that the fact that the fish had not fed on the most abundant Gastropoda after Diptera in the stream may be related to the assumption that these relatively immobile gastropods seem like stones to the fish due to their hard shells. Barbus cyclolepis is a rheophilic species that prefers riffle and run habitats at all stations along the Istranca Stream (Saç and Özuluğ, 2017). In addition, riffle zones are rich feeding areas for this fish, as strong currents increase invertebrate density (Freyhof, 1996). In these habitats, the fish are thought to prefer more mobile insects that drift with the current rather than immobile organisms that fix themselves on the ground, such as the gastropods.
Rozdina et al. (2008) also could not find gastropods in the digestive tract of $B$. cyclolepis and thought that molluscs, which were detected at a very low rate, probably accidentally got into the diet of the fish. In addition, while some species belonging to the genus do not prefer gastropods or other molluscs as food (Dadebo et al., 2013; Sapounidis et al., 2015), in some other species these prey items were represented with low proportions (Collares-Pereira et al., 1996; Pires et al., 2001; Piria et al., 2005).

Crustacea found in the diet of $B$. cyclolepis consists of Gammaridae. While the abundance of Gammaridae in the environment was high in spring, this value has sharply decreased in the summer. Gammarids reproduce throughout most of the year but there is a pronounced peak of activity in spring and early summer. Additionally, stream warming has considerable negative effects on the reproductive processes of some Gammaridae species that would potentially reduce the reproductive capacity of these organisms (Pöckl et al., 2003). Therefore, it is thought that the decrease in the abundance of Gammaridae in summer might be related to the water temperature (Saç and Özuluğ, 2017).

The values of the electivity index, which ranged from -1 to +1 , are related to the presence/absence of food items in the digestive tract of fish in relation to their abundance in the environment. Hemiptera, Gastropoda and Bivalvia were captured in the study area during these two seasons but none of them was found in the digestive tract of the fish; so, the electivity index for these groups was -1 . The values of the electivity index also showed that $B$. cyclolepis had a high selectivity (+1) for Hymenoptera and Arachnida. The hymenopteran parts or extremities found in the digestive tract of $B$. cyclolepis, belong to Formicidae (ants). Formicidae is not aquatic, but it is possible that specimens drifted by flow were accidentally consumed by the fish. Arachnida found in the diet of $B$. cyclolepis consists of members of the Acaridae. According to Gerecke and Di Sabatino (2007), a typical macroinvertebrate sample that could provide a more representative idea about the investigated mite fauna is often not adequate for two reasons: (1) collecting is generally done with a too large mesh size (300 $\mu \mathrm{m}$ or more); and (2) sorting generally concentrates on animals of a larger size at low magnification; consequently, many mites are overlooked. Water mites were probably not represented in the benthos sample because the mesh size of the special hand net grab was too large $(250 \mu \mathrm{m})$ to retain these small-bodied macroinvertebrates or they may have been overlooked during the sorting of samples.

The proportions of some macroinvertebrates (Ephemeroptera, Plecoptera, Odonata, Coleoptera and Hemiptera) in the environment were relatively low. The low values of these organisms overlapped by the low percentage of their occurrence in the diet of fish (Table 4). However, it is noteworthy that, especially in summer, the value of Trichoptera in the environment is quite low while its value in the stomach is high (Table 2, Table 3). The fact that 
macroinvertebrates were collected from a limited area at each sampling station and that conversely, $B$. cyclolepis is relatively more mobile along the stream is considered as evidence that the fish exhibits selective feeding on Trichoptera (Table 4).

\section{CONCLUSION}

In conclusion, it is thought that the answers to the targeted questions were reached with the results of this study. Firstly, the diet of $B$. cyclolepis consisted of 11 different food items collected in five major groups, mainly Insecta. The main food item in its diet is Diptera larvae, which have high

\section{REFERENCES}

Antal, L., László, B., Kotlík, P., Mozsár, A., Czeglédi, I., Oldal, M., Kemenesi, G., Jakab, F. \& Nagy, S. A. (2016). Phylogenetic evidence for a new species of Barbus in the Danube River basin. Molecular Phylogenetics and Evolution, 96, 187-194. DOI: 10.1016/j.ympev.2015.11.023

Askew, R.R. (1988). Keys to the final-instar larvae of European Odonata, the dragonflies of Europe, Harley; Colchester-England. 194-211 pp.

Bouchard, R.W.Jr. (2012). Guide to aquatic invertebrate families of Mongolia identification manual for students, Citizen Monitors, and Aquatic Resource Professionals. Available Online. $218 \mathrm{pp}$.

Collares-Pereira, M., Martins, M.J., Pires, A.M., Geraldes, A.M. \& Coelho, M. (1996). Feeding behavior of Barbus bocagei assessed under a spatiotemporal approach. Folia Zoologica, 45 (1), 65-76.

Dadebo, E., Mohammed, A. \& Sorsa, S. (2013). Food and feeding habits of the straightfin barb Barbus paludinosus (Peters, 1852) (Pisces: Cyprinidae) in Lake Ziway, Ethiopia. Ethiopian Journal of Biological Sciences, 12(2), 135-150.

Freyhof, J. (1996). Distribution of YOY-barbel Barbus barbus (L.) in the River Sieg/Germany. Conservation of Endangered Freshwater Fish in Europe. $\begin{array}{llll}\text { A. Kirchhofer \& D. Hefti (Eds.), 259-267. } & \end{array}$ DOI: 10.1007/978-3-0348-9014-4_25

Gerecke, R. \& Di Sabatino, A. (2007). Water mites (Hydrachnidia and Halacaridae) in spring habitats: a taxonomical and ecological perspective. In: Cantonati, M., Bertuzzi, E., Spitale, D. (eds) The spring habitat: biota and sampling methods. Museo Tridentino di Scienze Naturali, Trento (Monografi e del Museo Tridentino di Scienze Naturali 4). Marco Cantonati at Museo delle Scienze, Trento, pp 193-216.

Gülbunar, F., Aydın, G.B. \& Çamur-Elipek, B. (2018). The growth of Tanypus punctipennis Meigen (Diptera, Chironomidae) larvae in laboratory conditions and the effects of water temperature and $\mathrm{pH}$. Trakya University Journal of Natural Sciences, 19 (1), 101-105. DOI: $10.23902 /$ trkjnat.356750

Hamid, S.A. \& Rawi, C.S.M. (2017). Application of aquatic insects (Ephemeroptera, Plecoptera And Trichoptera) in water quality assessment of Malaysian headwater. Tropical Life Sciences Research, 28(2), 143-162. DOI:10.21315/tlsr2017.28.2.11

Hayse, J.W. (1990). Feeding habits, age, growth, and reproduction of Atlantic spadefish Chaetodipterus faber (Pisces: Ephippidae) in South Carolina. Fishery Bulletin, 88 (1), 67-83.

Hurlbert, S. H. (1978). The measurements of niche overlap and some relatives. Ecology, 59, 67-77. DOI:10.2307/1936632

Hyslop, E.J. (1980). Stomach contents analysis-a review of methods and their application. Journal of Fish Biology, 17, 411-429. DOI:10.1111/j.1095-8649.1980.tb02775.x

Keiper, J.B., Walton, E.W. \& Foote, B.A. (2002). Biology and ecology of higher Diptera from freshwater wetlands. Annual Review of Entomology, 47, 207-232. DOI: 10.1146/annurev.ento.47.091201.145159 importance values, so this feeding habit has resulted in a narrow niche width. Secondly, there was a relationship between the proportion of consumed food items by the fish and their ratios in the environment. The fish was fed with every organism detected in the environment except Gastropoda, Bivalvia and Hemiptera. However, despite the relatively high proportions of some organisms such as Crustacea and Gastropoda in the environment, B. cyclolepis was selective mostly on Diptera, which is the easiest prey for itself. Seasonal activity, both in the feeding of fish and occurrences of the macroinvertebrates in the environment resulted in high values in summer.
Kocataş, A. (2008). Ekoloji ve Çevre Biyolojisi. Ege Üniversitesi Fen Fakültesi Ders Kitapları Serisi, 10. Baskı, 585pp., Bornova/İzmir (in Turkish).

Kottelat, M. \& Freyhof, J. (2007). Handbook of European freshwater fishes. Kottelat, Cornol \& Freyhof, Berlin, xiv + 646 pp.

Krebs, C.J. (1998). Ecological methodology. Addison-Wesley Educational Publishers, Menlo Park, CA.

Levins, R. (1968). Evolution in changing environments. Princeton University Press, Princeton. DOI:10.1515/9780691209418

López-López, E. \& Sedeńo-Díaz, J.E. (2015). Biological Indicators of Water Quality: The Role of Fish and Macroinvertebrates as Indicators of Water Quality. In R.H. Armon \& O. Ha"nninen (eds.), Environmental Indicators, Springer Science+Business Media Dordrecht. DOI:10.1007/978-94-017-9499-2_37

Nilsson, A. (1996). Aquatic Insects of North Europe. A taxonomic handbook. Vol.1: Ephemeroptera. Plecoptera, Heteroptera, Megaloptera, Neuroptera, Coleoptera, Trichoptera and Lepidoptera, Apollo Books, Denmark, 274 pp., ISBN 87-88757-09-9.

Nilsson, A. (1997). Aquatic insects of northern Europe. A taxonomic handbook, Vol. 2: Odonata. Diptera, Apollo Books, Denmark, 440 pp. ISBN 87-88757-15-3.

Novakowski, G.G., Hahn, N.S. \& Fugi, R. (2008). Diet seasonality and food overlap of the fish assemblage in a Pantanal Pond. Neotropical Ichthyology, 6 (4), 567-576. DOI: 10.1590/S1679-62252008000400004

Oscoz, J., Galicia, D. \& Miranda R. (2011). Identification guide of freshwater macroinvertebrates of Spain. Springer, London. 153 pp. ISBN: 978-94007-1553-0. DOI:10.1007/978-94-007-1554-7

Pinto T L.F. \& Uieda, V. S. (2007). Aquatic insects selected as food for fishes of a tropical stream: are there spatial and seasonal differences in their selectivity? Acta Limnologica Brasilliensia, 19 (1), 67-78.

Pires, A.M., Cowx, I. G. \& Coelho, M.M. (2001). Diet and growth of two sympatric Iberian barbel, Barbus steindachneri and Barbus microcephalus, in the middle reaches of the Guadiana Basin (Portugal). Folia Zoologica, 50 (2), 291-304.

Piria M., Treer, T., Anicic, I., Safner, R. \& Odak, T. (2005). The natural diet of five Cyprinid fish species. Agriculturae Conspectus Scientificus, 70 (1), 21-28.

Pöckl M., Webb, B.W. \& Sutcliffe, D.W. (2003). Life history and reproductive capacity of Gammarus fossarum and G. roeseli (Crustacea: Amphipoda) under naturally fluctuating water temperatures: a simulation study. Freshwater Biology, 48, 53-66. DOI: 10.1046/j.1365-2427.2003.00967.x

Rozdina, D., Raikova-Petrova, G., Marinova, R. \& Uzunova, E. (2008). Food spectrum and feeding of Barbus cyclolepis Heckel from the middle stream Maritza River (Bulgaria). Bulgarian Journal of Agricultural Science, 14 (2), 209-213. 
Sapounidis, A.S., Koutrakis, E.T. \& Leonardos I.D. (2015). Life history traits, growth and feeding ecology of a native species (Barbus strumicae Karaman, 1955) in Nestos River, a flow regulated river in Northern Greece. North-Western Journal of Zoology, 11 (2), 331-34.

Saç, G. \& Özuluğ, M. (2017). Effects of environmental variables on the distribution of fish assemblages in an endorheic stream (İstanbul, Turkey). Fresenius Environmental Bulletin, 26 (12), 7150-7159.

Saç, G. \& Özuluğ, M. (2020a). Life history pattern and feeding habits of Gobio bulgaricus (Drensky, 1926) (Pisces: Gobionidae) in an endorheic stream (Istranca Stream, Turkey). Iranian Journal of Fisheries Sciences, 19 (1), 248-261.
Saç, G. \& Özuluğ, M. (2020b). Life-history traits of Phoxinus strandjae Drensky, 1926 (Actinopterygii: Leuciscidae) from Istranca Stream, Turkey. Acta Zoologica Bulgarica, 72 (3), 429-438.

Thorp, J.H. \& Covich, A.P. (2001). Ecology and Classification of North American Freshwater Invertebrates. 2nd Ed., Academic Press, San Diego California. DOI:10.1016/B978-012690647-9/50002-8

Tupinambas, T.H., Pompeu, P.S., Gandini, C.V., Hughes, R.M. \& Callisto, M. (2015). Fishstomach contents in benthic macroinvertebrate assemblage assesments. Brazillian Journal of Biology, 75 (1), 157-164. DOI:10.1590/1519-6984.09913

Zwick, P. (2004). Key to the west Palaearctic genera of stoneflies (Plecoptera) in the larval stage, Limnologica, 34, 315-348. DOI:10.1016/S0075-9511(04)80004-5 